\title{
Pengaruh Insentif Finansial dan Non Finansial terhadap Kinerja Karyawan Hotel Timeshare dengan Variable Mediasi Kepuasan Kerja
}

\author{
Ni Luh Dita Priliani*1, Ida Ayu Putri Widawati², Irene Hanna H. Sihombing3 \\ 1,2,3 Magister Terapan Pariwisata, Politeknik Pariwisata Bali \\ Jl. Dharmawangsa, Kampial, Nusa Dua. Ph. (0361) 773537 \\ 1prilianidita2@gmail.com, 2putri7widawati@gmail.com, 3irenesihombing@ppb.ac.id \\ *Corresponding author
}

\begin{tabular}{l|l|l} 
Received: Oktober, 2021 & Accepted: November, 2021 & Published: Desember, 2021
\end{tabular}

\begin{abstract}
Employee performance is seen as what an employee does and what he doesn't do. Employee performance involves the quality and quantity of output, attendance at work, and timeliness of output. The level of absenteeism is quite high where an average of $14.59 \%$ per month. This can have a negative effect on employee performance, meaning that the higher the level of absenteeism will affect the lower performance of the employee. There are indications that employee job satisfaction is not optimal due to inaccurate provision of financial and nonfinancial incentives. Given this phenomenon, it is interesting to study given the tendency of low employee performance, the possibility of giving inappropriate or unsatisfactory incentives which causes low job satisfaction. Data were collected using a questionnaire method to 104 respondents at Karma Royal Bali. Data were analyzed using SmartPLS software. The results are that financial incentives and non-financial incentives have a positive and significant effect on job satisfaction and job satisfaction as a mediator between financial incentives and non-financial incentives on employee performance at Karma Royal Bali.
\end{abstract}

Keywords: incentives, job satisfaction, employee performance

\begin{abstract}
Abstrak
Kinerja karyawan dianggap sebagai apa yang dilakukan karyawan dan apa yang tidak dilakukannya. Kinerja karyawan melibatkan kualitas dan kuantitas output, kehadiran di tempat kerja, serta ketepatan waktu output. Tingkat absensi cukup tinggi dimana rata-rata 14,59\% setiap bulannya. Hal ini dapat berpengaruh secara negatif terhadap kinerja karyawan, artinya semakin tinggi tingkat absensi akan mempengaruhi rendahnya kinerja dari karyawan. Adanya indikasi mengenai kepuasan kerja karyawan yang tidak maksimal dikarenakan pemberian insentif finansial dan insentif non finansial kurang tepat. Dengan adanya fenomena tersebut, menarik untuk diteliti mengingat adanya kecenderungan kinerja karyawan yang rendah kemungkinan pemberian insentif yang kurang tepat atau dirasa kurang memuaskan yang menyebabkan kepuasan kerja rendah. Data dikumpulkan dengan metode kuisioner terhadap 104 responden di Karma Royal Bali. Data dianalisis dengan
\end{abstract}


Pengaruh Insentif Finansial dan Non Finansial terhadap Kinerja Karyawan Hotel Timeshare dengan Variable..

Ni Luh Dita Priliani, Ida Ayu Putri Widawati, Irene Hanna H. Sihombing

menggunakan software SmartPLS 2.0M. Hasilnya adalah insentif finansial dan insentif non finansial berpengaruh positif dan signifikan terhadap kepuasan kerja dan kepuasan kerja menjadi mediator antara insentif finansial dan insentif non finansial terhadap kinerja karyawan di Karma Royal Bali.

\section{Kata kunci: insentif, kepuasan kerja, kinerja karyawan}

\section{PENDAHULUAN}

Kinerja sudah menjadi terminologi atau konsep penting pada berbagai pembahasan khususnya dalam menggerakkan keberhasilan organisasi serta sumber daya manusia. Kinerja karyawan dianggap sebagai apa yang dilakukan dan yang tidak dilakukan oleh karyawan. Kinerja karyawan mengimplikasikan pada kualitas dan kuantitas output, kehadiran di tempat kerja, serta ketepatan waktu output yang dikerjakan. Hasil penelitian (Yang, 2008) pada kinerja individu menunjukkan bahwa kinerja individu tidak bisa diverifikasi kebenarannya. Sejalan dengan penelitian yang dilakukan oleh (Yang, 2008), (Bishop et al., 1987) menganalisis kinerja karyawan dan menyatakan bahwa pengakuan serta penghargaan terhadap kinerja karyawan mengarahkan kepada diskriminasi antara produktivitas.

Interaksi antara insentif berupa penghargaan dan kinerja karyawan sangat penting bagi keberhasilan organisasi (Kuznetsova, 2015). Organisasi saat ini berusaha untuk menarik dan mempertahankan karyawan berbakat karena karyawan berbakat berdampak positif pada kinerja organisasi (Jawabreh \& Alsarayreh, 2017). Akibatnya, organisasi harus menyusun sistem yang efektif yang berkontribusi pada pengembangan sikap di antara karyawan dan akan meningkatkan kinerja mereka. Telah ditemukan bahwa insentif seperti promosi dan bonus meningkatkan kinerja karyawan dan mengurangi turnover karyawan dimana selanjutnya karyawan hanya loyal ketika keinginan mereka terpenuhi (Jawabreh \& Alsarayreh, 2017).

Pemberian insentif kepada karyawan merupakan salah satu hal pokok yang harus diperhatikan oleh sebuah perusahaan. Baik tidaknya kinerja karyawan bisa pula disebabkan oleh besar atau kecilnya insentif yang diterima oleh karyawan. Penelitian (Jaworski et al., 2018) menjelaskan bahwa kinerja yang baik timbul karena adanya kepuasan kerja yang dipenuhi dengan memberikan insentif. Namun, kepuasan kerja karyawan bersifat sangat individual, sehingga masing-masing karyawan memiliki kepuasan kerja yang berbeda-beda searah dengan sistem nilai yang berlaku pada dirinya (Wardhani et al., 2015).

Hasil penelitian dari (Arindiah, 2010) terdapat pengaruh secara tidak langsung pemberian insentif memberikan pengaruh yang signifikan terhadap kinerja melalui kepuasan kerja. Kepuasan kerja merupakan hasil evaluasi yang menggambarkan seseorang atas perasaan sikapnya senang atau tidak senang, puas atau tidak puas dalam melakukan pekerjaannya, di mana tingkat kepuasan kerja karyawan salah satunya dapat ditentukan dengan seberapa besar karyawan yang bersangkutan menilai kompensasi atau insentif yang diterima dari perusahaan sudah atau belum sesuai dengan harapannya. (Zaputri et al., 2013) menyatakan bahwa pengaruh insentif terhadap kepuasan kerja dan kinerja karyawan jika dirinci secara skematis dapat dilukiskan sebagai existing dari variabel kepuasan kerja yang berfungsi sebagai variabel mediasi. Pengaruh insentif terhadap kinerja karyawan akan lebih bermakna jika dimediasi oleh variabel kepuasan kerja.

Timeshare pertama kali masuk di Indonesia pada tahun 1985 dan menjadi dikenal oleh dunia pariwisata Indonesia pada tahun 1992. Karma Grup merupakan satu-satunya penyedia akomodasi berbasis timeshare yang berada di Bali. Karma Grup memiliki 6 properti yang terletak di beberapa kawasan di Bali. Karma Grup pertama kali membuka 
propertinya yakni pada tahun 1996. Penelitian akan dilakukan pada tiga properti yang dikhususkan untuk member karena adanya isu tentang kinerja karyawan yang rendah. Berdasarkan observasi dan wawancara awal dengan Manajer di Karma Royal Candidasa, Jimbaran dan Sanur terdapat indikasi rendahnya kinerja karyawan. Evaluasi dan penilaian kinerja karyawan dilakukan secara berkala setiap satu tahun dua kali yang dilakukan oleh atasan dari masing-masing departemen. Penilaian kinerja dilakukan dengan self-appraisal, guest comment card, absensi dan ketepatan penyelesain pekerjaan.

Tingkat absensi cukup tinggi dimana rata-rata 14,59\% setiap bulannya. Tingkat absensi dapat berpengaruh secara negatif terhadap kinerja, yang artinya semakin tinggi tingkat absensi karyawan maka akan mempengaruhi rendahnya kinerja karyawan. Hasil penilaian yang dilakukan oleh Manajer, Manajer mengatakan bahwa terlihat beberapa karyawan yang selalu datang terlambat serta pulang mendahului jam kerja yang seharusnya, jam istirahat melebihi batas waktu istirahat, serta penyelesaian tugas tepat waktu namun hasil yang kurang maksimal yang menunjukkan indikasi menurunnya kinerja karyawan.

Berdasarkan hasil wawancara yang telah dilakukan dengan beberapa karyawan, rendahnya kinerja mereka karena kepuasan kerja mereka dalam hal pemberian insentif masih rendah. Insentif di Karma Royal dapat dibagi menjadi dua yaitu, insentif finansial dan insentif non finansial. Insentif finansial yang diterima oleh karyawan tiap bulannya mengalami fluktuasi (tidak tetap). Salah satu finansial yang sangat berpengaruh terhadap pemberian insentif finansial sebuah hotel adalah service charge. Service Charge lebih dominan didapatkan dari penjualan makanan dan minuman karena Karma Royal Bali tidak mendapatkan service charge dari penjualan kamar dengan berbasis Timeshare Hotel.

Karyawan juga berpendapat, pembagian dari insentif finansial yang diberikan tidak terbuka perhitungannya antara pihak manajemen dengan karyawan. Karyawan merasa adanya ketidakadilan dalam pembagian insentif yang diberikan. Pihak manajemen tidak memberikan data terkait pendapatan hotel yang didapat setiap bulannya kepada karyawan. Pada insentif non finansial, pihak manajemen tidak menyediakan rekreasi sehingga meningkatnya kejenuhan kerja yang menurunkan kinerja karyawan. Tidak adanya pengembangan karir seperti promosi juga dirasakan oleh karyawan. Pihak manajemen lebih memilih untuk mencari karyawan baru untuk menduduki posisi baik sebagai supervisor maupun resort manager yang belum terisi.

Berdasarkan penjelasan fenomena lokal dan data yang didapatkan, menarik untuk dilakukan penelitian mengingat adanya kecenderungan rendahnya kinerja karyawan kemungkinan pemberian insentif yang kurang tepat atau dirasa kurang memuaskan yang menyebabkan kepuasan kerja rendah. Maka perlu dilakukan penelitian dimana untuk menguji pengaruh insentif baik finansial maupun non finansial terhadap kinerja karyawan dengan kepuasan kerja sebagai variabel pemediasi.

Insentif dan kepuasan kerja memiliki keterkaitan antara satu dengan lainnya. Insentif sebagai perangsang kepuasan kerja yang mampu memberikan dorongan dalam melakukan pekerjaannya dengan baik. Menurut Sarwoto (2002), Penggolongan insentif dibedakan menjadi dua yaitu insentif finansial atau insentif material dan Insentif non finansial atau insentif non material. Ranupandojo dan Husnan (1999) menyatakan bahwa insentif yang dimaksud perusahaan terutama agar dapat meningkatkan produktivitas karyawan serta mempertahankan karyawan berprestasi untuk tetap berada dalam organisasi atau perusahaan.

Mengacu pada hasil penelitian (Puspitawati, Ni Made Dwi \& Riana, 2014) adapun indikator yang digunakan untuk menilai kepuasan kerja karyawan meliputi (1) Beban kerja, (2) Gaji, (3) Promosi, (4) Pengawas, (5) Rekan kerja. Indikator yang digunakan untuk mengukur kepuasan memiliki keterkaitan dengan insentif. Keterkaitan Insentif 
Pengaruh Insentif Finansial dan Non Finansial terhadap Kinerja Karyawan Hotel Timeshare dengan Variable.. Ni Luh Dita Priliani, Ida Ayu Putri Widawati, Irene Hanna H. Sihombing

finansial dan insentif non finansial didalam poin dua dan tiga. Kepuasan kerja merupakan perasaan prestasi serta keberhasilan pekerja dalam melakukan pekerjaannya.

Industri Perhotelan khususnya di Bali adalah perusahaan yang padat karya sehingga dapat menekan pengangguran dan memperbaiki perekonomian masyarakat. Menurut Stoner (dalam (Setiyadi et al., 2016)), mengemukakan bahwa kinerja adalah fungsi dari perangsang, kapabilitas, serta persepsi kontribusi. Performance atau kinerja biasanya diberi batasan sebagai keberhasilan seseorang di dalam menjalankan tugas-tugas atau seluruh pekerjaan yang dibebankan kepadanya. Bono dan Judge (dalam (Indrasari, 2017)) menilai kinerja dari berbagai aspek. Ada tujuh kriteria yang digunakan dalam menilai kinerja karyawan secara individu antara lain: (1) Kualitas, (2) Produktifitas, (3) Ketepatan waktu, (4) Efektivitas, (5) Kemandirian, (6) Komitmen kerja, (7) Tanggung jawab.

Timeshare pertama kali masuk di Indonesia pada tahun 1985 dan menjadi dikenal oleh dunia pariwisata Indonesia pada tahun 1992. Tahun 1994, komunitas Timeshare di Indonesia telah mendirikan sebuah asosiasi yaitu Indonesian Timeshare Association (ITA) yang didukung oleh pemerintah dengan dikeluarkannya peraturan tentang Timeshare dengan Keputusan Menteri Pariwisata, Pos dan Telekomunikasi (Menparpostel) No; KM.57/PW./102/ MPPT96 dimana kemudian diubah sebagai Keputusan Menteri Pariwisata, seni dan Kebudayaan No. 5-413/M-PSB/98, tertanggal 13 Desember 1998 serta terakhir peraturan itu dicabut oleh Menteri pariwisata dan Kebudayaan No. Kep 01/MNPK/2000. Sejak Keputusan Menteri Pariwisata dan Kebudayaan yang terakhir, kemudian tidak adanya hukum serta peraturan yang secara langsung digunakan pada bisnis timeshare tersebut. Peraturan terakhir tersebut bertujuan agar memindahkan kebijakan dari Menteri Pariwisata dan Kebudayaan kepada Departemen Perdagangan dan Industri, namun keputusan tersebut menimbulkan perdebatan publik.

Industri timeshare memiliki kekuatan kompetitif strategis dalam sumber daya manusia dan kualitas produk. Salah satu kekuatan terbesar industri adalah adaptasi produk dengan kebutuhan dan permintaan konsumen. Perusahaan timeshare harus fokus pada kekuatan ini, dan terus mendorong adaptasi produk untuk memenuhi kebutuhan konsumen yang terus berkembang. Ada peluang yang signifikan untuk pengembangan dan profitabilitas di banyak pasar, segmen, dan penawaran produk. Peluang signifikan untuk ekspansi global dan segmen demografis yang sebelumnya diabaikan. Industri timeshare menghadapi ancaman terhadap sumber daya, baik manusia maupun modal. Manajemen timeshare dan waktu tambahan pada pendidikan dan pengembangan sumber daya manusia agar dapat membantu membuat karyawan biasa bekerja dengan cara yang luar biasa (O’Reilly \& Pfeffer, 2000).

Tujuan dari penelitian ini adalah (1) Menganalisis pengaruh antara insentif finansial terhadap kepuasan kerja. (2) Menganalisis pengaruh antara insentif non finansial terhadap kepuasan kerja. (3) Menganalisis pengaruh antara kepuasan kerja terhadap kinerja karyawan. (4) Menganalisis pengaruh antara insentif finansial terhadap kinerja karyawan. (5) Menganalisis pengaruh antara insentif non finansial terhadap kinerja karyawan. (6) Menganalisis kepuasan kerja memediasi pengaruh antara insentif finansial terhadap kinerja karyawan. (7) Menganalisis kepuasan kerja memediasi pengaruh antara insentif non finansial terhadap kinerja karyawan.

\section{METODE PENELITIAN}

Penelitian ini yang dilakukan adalah penelitian kuantitatif melalui pendekatan kausalitas. Pendekatan kausalitas berfungsi untuk menganalisa bagaimana satu variabel mempengaruhi variabel atau hubungan antara satu variabel dengan variabel lainnya. Metode penelitian yang bersifat kuantitatif berdasarkan (Sugiyono, 2007), yakni metode penelitian yang berlandaskan kepada positivisme, yang digunakan untuk meneliti sampel serta populasi penelitian dimana teknik pengumpulan sampel umumnya dilaksanakan 
dengan random, sedangkan pengumpulan data dilaksanakan dengan teknik memanfaatkan instrumen pada penelitian dimana selanjutnya dianalisis secara terukur dengan tujuan menguji hipotesis yang ditetapkan selanjutnya.

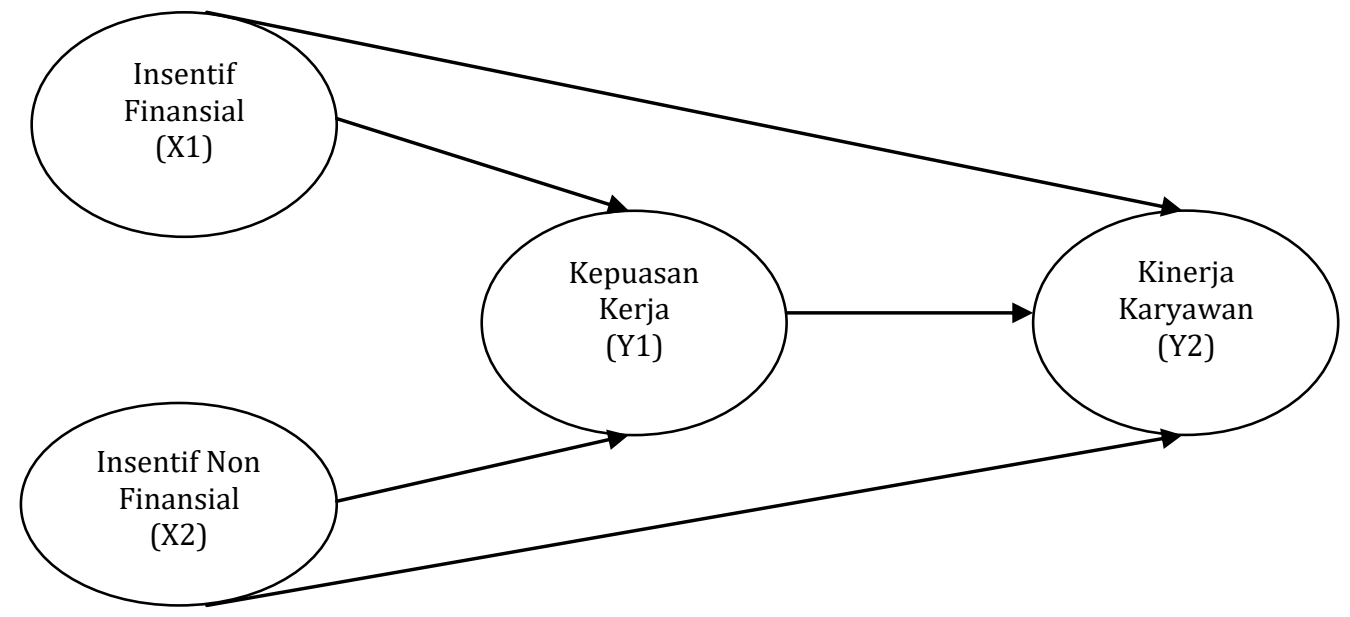

Gambar 1. Kerangka Konsep Penelitian

[Sumber: Data diolah, 2018]

Berdasarkan (Sugiyono, 2007) Populasi adalah wilayah abstraksi yang terdiri dari subjek atau objek yang memiliki kualitas serta karakteristik spesifik tertentu yang telah ditetapkan oleh peneliti untuk dianalisa dan kemudian di tarik kesimpulan. Sampel merupakan komponen dari karakteristik dan jumlah yang dimiliki oleh populasi (Sugiyono, 2007). Populasi dalam penelitian ini merupakan karyawan tetap di Karma Royal Bali yang berjumlah 104 orang. Ukuran sampel pada penelitian ini merupakan 104 responden. Sampling jenuh merupakan metode yang digunakan, dimana semua anggota dari populasi sebagai sampel.

Dalam penelitian ini teknik yang digunakan untuk mengumpulkan data dapat menggunakan tiga metode, terdiri dari observasi, wawancara (interview) dan kuisioner. Selanjutnya model penelitian akan dianalisa menggunakan Structural Equation Modeling (SEM), menggunakan software PLS (Partial Least Square). Dalam uji analisis, PLS memakai dua evaluasi yaitu model pengukuran yakni model pengukuran untuk menguji validitas dan reliabilitas (outer model) dan model struktural yang digunakan untuk menguji kausalitas atau pengujian hipotesis untuk menguji dengan model prediksi (inner model).

\section{HASIL DAN PEMBAHASAN}

\subsection{Deskripsi Data}

Data yang digunakan pada penelitian diperoleh dari hasil sebaran kuisioner kepada seluruh responden dengan jumlah 104 responden. Berikut Tabel 1 yang merupakan hasil dari karakteristik responden sebagai berikut:

Tabel 1: Distribusi Karakteristik Responden

[Sumber: Hasil Analisis Data Primer, 2020]

\begin{tabular}{crc}
\hline Karakteristik & Jumlah & Persentase \\
\hline & Jenis Kelamin & \\
Laki-Laki & 67 & $64 \%$ \\
Perempuan & 37 & $36 \%$ \\
\hline
\end{tabular}




\begin{tabular}{crc}
\hline \multicolumn{3}{c}{ Usia } \\
20-30 Tahun & 12 & $12 \%$ \\
31-40 Tahun & 70 & $67 \%$ \\
$>40$ Tahun & 22 & $21 \%$ \\
\hline & Pendidikan \\
SMA $/ \mathrm{K}$ & 54 & $52 \%$ \\
Diploma & 44 & $42 \%$ \\
Sarjana & 6 & $6 \%$ \\
\hline & Lama Bekerja & \\
$<5$ Tahun & 19 & $18 \%$ \\
$\geq 5$ Tahun & 85 & $82 \%$ \\
\hline Jumlah & $\mathbf{1 0 4}$ & $\mathbf{1 0 0} \%$ \\
\hline
\end{tabular}

Berdasarkan Tabel 1 dapat dilihat jenis kelamin terbanyak adalah laki-laki yakni $64 \%$, berdasarkan usia terbanyak diketahui pada rentang umur 31-40 tahun yakni 67\%. Hasil penelitian menunjukkan bahwa responden merupakan kelompok usia produktif secara ekonomi. Dimana dalam satu departemen di dominasi dengan jenis kelamin lakilaki. Kemudian umur yang paling rendah adalah umur 20-30 tahun yang merupakan level junior yang siap menerima proses kaderisasi oleh senior. Sedangkan, karyawan yang memiliki usia di atas dari 40 tahun, serta memiliki masa kerja lebih dari 5 tahun di Karma Royal Bali. Beberapa karyawan berada di posisi rank \& file telah menerima penghargaan pengabdian selama 20 tahun. Karyawan tersebut tetap berada di posisi rank \& file yang bertahan dikarenakan peluang untuk mendapatkan pekerjaan baru yang menerima pada usia tersebut sangat sedikit.

Berdasarkan tingkat pendidikan diketahui yang terbanyak adalah SMA/K dengan persentase 52\%, hal ini menunjukkan bahwa pihak hotel merekrut sumber daya manusia dengan level pendidikan menengah yang ditugaskan pada level teknis berupa pelayanan tamu di lapangan/kontak langsung dengan tamu. Untuk pendidikan tingkat Diploma lebih banyak menduduki posisi supervisor. Tidak menutup kemungkinan juga, karyawan rank \& file ada yang memiliki latar belakang pendidikan Diploma dan Sarjana dimana karyawan tersebut merupakan fresh graduate yang baru memulai karir di industri pariwisata.

Sedangkan berdasarkan lama bekerja terbanyak adalah $\geq 5$ tahun yakni $82 \%$. Karyawan yang memiliki rentang usia dari 30 - 40 tahun serta di atas 40 tahun yang telah bekerja $\geq 5$ tahun. Hal ini menunjukkan bahwa karyawan Karma Royal Bali merupakan karyawan yang berpengalaman, yang sudah memahami hak dan kewajiban sebagai karyawan. Berdasarkan rentang waktu yang cukup lama bekerja di Karma Royal Bali, dapat dilihat bahwa pemahaman antara hak dan kewajiban yang diterapkan oleh pihak manajemen sudah dimengerti dan karyawan mengetahui bagaimana pembaharuan dan perkembangan dari tahun ke tahun.

\subsection{Pembahasan}

Keempat variabel memiliki nilai loading factor lebih besar dari 0.5, sehingga dapat disimpulkan bahwa indikator individu dianggap reliabel. Pada uji discriminant validity semua indikator individu yang digunakan pada penelitian ini dapat dinyatakan valid karena hasil keempat variabel memiliki nilai AVE diatas 0,50 dan semua variabel memiliki nilai akar AVE lebih tinggi dari koefisien korelasi antar satu variabel dengan variabel lainnya. Selain itu masing-masing variabel memiliki nilai Composite Reliability sebagai berikut, Insentif finansial (X1) sebesar 0,965, Insentif non finansial (X2) 0,962, Kepuasan kerja (Y1) sebesar 0,892 dan Kinerja karyawan (Y2) sebesar 0,917, berdasarkan hasil 
tersebut nilai yang dihasilkan lebih besar dari 0.700 dapat disimpulkan bahwa variabel yang digunakan dapat dinyatakan reliabel.

Nilai R-square dari variabel kepuasan kerja sebesar 0,689 dan variabel kinerja karyawan 0,878. Semakin tinggi nilai R-square, jadi semakin besar kemampuan variabel eksogen dapat dijelaskan oleh variabel endogen sehingga semakin baik persaman struktural. Model struktural dievaluasi dengan cara memperhatikan $\mathrm{Q}^{2}$ predictiverelevance model yang digunakan untuk mengukur seberapa baik nilai observasi yang dihasilkan oleh model. Koefisien determinasi seluruh variabel dependen berdasarkan dari $\mathrm{Q}^{2}$. Besaran $\mathrm{Q}^{2}$ mempunyai nilai dengan rentang $0<\mathrm{Q}^{2}<1$, semakin mendekati nilai 1 berarti model semakin baik. Nilai predictive-relevance $\left(\mathrm{Q}^{2}\right)$ dirumuskan dengan:

$\mathrm{Q}^{2}=1-\left(1-\mathrm{R} 1^{2}\right)\left(1-\mathrm{R} 2^{2}\right)(1)$

dimana $\mathrm{Q}^{2}$ adalah predictive-relevance dan $\mathrm{R}$ adalah nilai R-square (1).

Apabila $Q^{2}$ lebih besar dari 0 , diinterpretasikan model cukup baik, artinya mampu menjelaskan fenomena variabel kinerja karyawan sebesar nilai $\mathrm{Q}^{2}$ tersebut.

Dapat dihitung nilai predictive-relevance $\left(Q^{2}\right)$, yakni: $1-(1-0,689)(1-0,878)=$ 0,96 . Berdasarkan hasil perhitungan menunjukkan nilai Q lebih besar dari $0(0,96>0)$. Hal ini dapat diinterpretasikan bahwa model baik memiliki nilai prediktif yang relevan, yaitu 96\% variasi pada variabel kinerja karyawan mampu dijelaskan oleh variabel-variabel yang digunakan dalam hal ini adalah insentif finansial, insentif non finansial dan kepuasan kerja, sedangkan sisanya $4 \%$ dijelaskan oleh variabel lain yang belum masuk ke dalam model.

Tabel 2: Hasil Pengujian Hipotesis

[Sumber: Hasil Analisis Data Primer, 2020]

\begin{tabular}{cccc}
\hline Hipotesis & Bootsrapping & T-Statistic & Kesimpulan \\
\hline Hipotesis 1 & 0,587143 & 8,112693 & H1 Diterima \\
Hipotesis 2 & 0,295917 & 3,664167 & H2 Diterima \\
Hipotesis 3 & 0,363114 & 4,55512 & H3 Diterima \\
Hipotesis 4 & 0,359783 & 4,751249 & H4 Diterima \\
Hipotesis 5 & 0,298057 & 5,287105 & H5 Diterima \\
Hipotesis 6 & 0,213 & 4,285 & H6 Diterima \\
Hipotesis 7 & 0,107 & 2,559 & H7 Diterima \\
\hline
\end{tabular}

Hasil analisis data secara statistik menunjukkan bahwa insentif finansial berpengaruh positif dan signifikan terhadap kepuasan kerja. Berdasarkan analisa model riset menunjukkan bahwa insentif finansial yang tinggi akan mengarah pada kepuasan kerja karyawan yang tinggi. Hasil analisis statistik deskriptif terkait dengan variabel insentif finansial di Hotel Karma Royal Bali menggunakan indikator service charge, tunjangan transport, bonus yang diberikan, tunjangan hari raya, komisi spa terbukti secara empiris dapat digunakan untuk mengukur insentif finansial dengan kategori tinggi. Penelitian ini sejalan dengan penelitian yang dilakukan dengan (Huang \& Lai, 2014) yang menyatakan insentif finansial memiliki pengaruh langsung terhadap kepuasan kerja. Kepuasan kerja dinyatakan meningkat jika adanya peningkatan dalam pemberian insentif finansial. Menurut karyawan hotel, insentif finansial yang diberikan oleh pihak manajemen memotivasi mereka untuk bekerja lebih keras lagi (Plessis et al., 2015).

Pertanyaan kedua dalam penelitian ini adalah bagaimana pengaruh antara insentif non finansial dengan kepuasan kerja yang setelah dilakukan pengujian hipotesis hasilnya analisis data secara statistik menunjukkan bahwa insentif non finansial berpengaruh positif dan signifikan terhadap kepuasan kerja. Berdasarkan analisa model riset menunjukkan bahwa 
insentif non finansial yang tinggi akan mengarah pada kepuasan kerja karyawan yang tinggi. Pada penelitian ini insentif non finansial menggunakan indikator tunjangan makan, pemberian cuti, tunjangan kesehatan, penghargaan pengabdian, kenaikan jabatan, serta penghargaan terbukti secara empiris merupakan indikator pembentuk variabel insentif non finansial yang digunakan untuk mengukur persepsi responden di Karma Royal Bali tentang insentif non finansial. Penelitian ini mendukung data empiris menyangkut pengaruh antara insentif non finansial terhadap kepuasan kerja. Sejalan dengan pernyataan (Al-Nsour, 2011) menyatakan insentif non finasial berupa liburan, job enrichment, promosi dan posisi kerja yang tepat.

Pertanyaan penelitian yang ketiga adalah bagaimana pengaruh antara kepuasan kerja dengan kinerja karyawan, berdasarkan pengujian hipotesis ditemukan secara statistik menunjukkan kepuasan kerja berpengaruh positif dan signifikan terhadap kinerja. Berdasarkan analisa model riset ini menunjukkan bahwa kepuasan kerja karyawan yang tinggi akan mengarah pada kinerja karyawan yang tinggi. Statistik deskriptif terkait dengan variabel kepuasan kerja dalam indikator penelitian menggunakan beban kerja, gaji, kenaikan jabatan, pengawas dan rekan kerja. Secara empiris telah terbukti dapat mengukur kepuasan kerja karyawan di Karma Royal Bali dengan kategori tinggi. Penelitian ini mendukung data empiris menyangkut pengaruh antara kepuasan kerja dan kinerja karyawan. Meningkatnya persaingan dalam dunia industri, perusahaan telah mengakui bagaimana pentingnya kinerja pada pekerjaan karyawan untuk dapat bersaing di pasar global karena ketika kinerja karyawan meningkat, maka akan mempengaruhi kinerja organisasi dan akhirnya tercapai profitabilitas seluruh organisasi. Kepuasan kerja menggambarkan bahwa betapa bahagianya seseorang dengan pekerjaannya (Khan et al., 2013). Dalam tinjauan sistematis literatur sebelumnya tentang karyawan hotel, ditemukan bahwa variabel yang paling banyak dipelajari adalah kepuasan kerja karena karyawan yang puas adalah faktor kunci dalam menghadapi tantangan yang dinamis dan terus meningkat untuk mempertahankan produktivitas organisasi (Dr. Vaishali \& Ms.Jyotsna, 2015). Hasil penelitian menyatakan ada pengaruh langsung positif kepuasan kerja terhadap kinerja.

Pertanyaan penelitian selanjutnya adalah bagaimana pengaruh antara insentif finansial dengan kinerja karyawan, dan setelah dilakukan uji hipotesis didapatkan hasil analisis data secara statistik menunjukan insentif finansial berpengaruh positif dan signifikan terhadap kinerja karyawan. Berdasarkan analisa model riset menunjukkan bahwa insentif finansial yang tinggi akan mengarah pada kinerja karyawan yang tinggi. Penelitian ini mendukung data empiris menyangkut pengaruh insentif finansial dengan kinerja karyawan. Sejalan dengan penelitian yang dilakukan oleh (Ndichu, 2017) melihat efek insentif finansial terhadap kinerja karyawan Bank di Kenya. Hasil dari penelitian menyatakan ada pengaruh positif antara insentif finansial dan kinerja karyawan. (Kashyap \& Goyal, 2006) mendefinisikan insentif sebagai sebuah variabel yang menjadi hadiah dan diberikan sesuai dengan variasi dalam pencapaian hasil tertentu. Hal ini dapat disebut sebagai stimulus atau pendorong untuk melakukan tindakan yang lebih besar.

Pertanyaan penelitian yang kelima adalah adalah bagaimana pengaruh insentif non finansial terhadap kinerja karyawan, berdasarkan hasil analisis data secara statistik menunjukkan bahwa insentif non finansial berpengaruh positif dan signifikan terhadap kinerja karyawan. Berdasarkan analisa model riset menunjukkan bahwa insentif non finansial yang tinggi akan mengarah pada kinerja karyawan yang tinggi. Penelitian ini mendukung data empiris menyangkut pengaruh insentif non finansial terhadap kinerja karyawan. Berbagai penelitian telah mengeksplorasi konsep insentif yang diberikan kepada karyawan dan skema pengakuan serta dampaknya terhadap motivasi dan kinerja karyawan. Demikian pula, secara simultan dan parsial, ada efek langsung positif dari insentif finansial pada kepuasan kerja. Secara bersamaan, ada efek tidak langsung dari 
insentif non finansial pada kinerja (Mayastinasari, 2013). Sejalan dengan penelitian yang dilakukan oleh (Ndege, 2014) menemukan korelasi yang tinggi antara manajemen penghargaan dan kinerja karyawan. Manajemen penghargaan dengan ini dipandang memiliki efek yang sangat berpengaruh pada kinerja karyawan sehingga semakin efisien organisasi mengelola penghargaannya, semakin baik kinerja karyawan. Namun, ini tidak boleh digunakan secara terpisah karena beberapa praktik manajemen penghargaan mungkin tidak layak secara finansial dalam jangka panjang jika tidak dilengkapi dengan praktik sumber daya manusia lainnya seperti job enrichment, organizational restructuring and job redesign.

Pertanyaan keenam yaitu bagaimana kepuasan kerja memediasi pengaruh antara insentif finansial dengan kinerja karyawan, hasil uji hipotesis menunjukan hasil analisis data secara statistik menunjukkan bahwa nilai t-statistics sebesar 4,285 sehingga analisa model riset menunjukkan bahwa insentif finansial yang tinggi berdampak pada kepuasan kerja karyawan sehingga kinerja karyawan pun akan meningkat.

Penelitian ini mendukung data empiris terkait kepuasan kerja memediasi pengaruh antara insentif finansial dengan kinerja karyawan. Penelitian ini sejalan dengan penelitian yang dilakukan oleh (Adisaksana et al., 2015) mengatakan terdapat pengaruh langsung maupun tidak langsung insentif finansial terhadap kinerja karyawan maupun melalui kepuasan kerja sebagai variabel intervening. Berdasarkan tinjauan literatur, tampaknya semua jenis insentif penting tetapi mereka memiliki arti yang berbeda untuk karyawan. Insentif yang berbeda mempengaruhi aspek yang berbeda dengan cara yang berbeda. Insentif finansial melalui kepuasan kerja dapat berpengaruh positif terhadap kinerja karyawan. Karyawan yang memiliki kepuasan kerja salah satunya dengan diberikan insentif finansial dapat meningkatkan kinerja karyawan (McQuillan, 1996).

Pertanyaan terakhir yaitu bagaimana kepuasan kerja memediasi pengaruh antara insentif non finansial dengan kinerja karyawan, hasil uji hipotesis yang didapat adalah hasil analisis data secara statistik menunjukkan bahwa nilai t-statistics sebesar 2,559. Berdasarkan analisa model riset menunjukkan bahwa insentif non finansial yang tinggi berdampak pada kepuasan kerja karyawan sehingga kinerja karyawan pun akan meningkat. Penelitian ini mendukung data empiris terkait kepuasan kerja memediasi pengaruh antara insentif non finansial dengan kinerja karyawan. Penelitian ini sejalan dengan penelitian Inti dari insentif adalah membangun pengaruh dengan perilaku yang diinginkan dan hasil yang membuat karyawan merasa dihargai (Whetten, 2007).

\section{KESIMPULAN}

Berdasarkan pembahasan hasil penelitian ini, maka kesimpulan yang didapat yaitu hasil analisis data secara statistik dengan nilai koefisien jalur sebesar 0,587 dengan nilai $t$ statistics sebesar 8,11 menunjukkan bahwa insentif finansial berpengaruh positif dan signifikan terhadap kepuasan kerja yang artinya insentif finansial yang tinggi akan mengarah pada kepuasan kerja karyawan yang tinggi. Hasil Insentif Non Finansial berpengaruh positif dan signifikan terhadap kepuasan kerja yang artinya menunjukkan bahwa insentif non finansial yang tinggi akan mengarah pada kepuasan kerja karyawan yang tinggi. Secara analisis data statistik ditunjukkan dengan koefisien jalur sebesar 0,295 dengan nilai $t$-statistics sebesar 3,664.

Kepuasan kerja berpengaruh positif dan signifikan terhadap kinerja yang artinya kepuasan kerja karyawan yang tinggi akan mengarah pada kinerja karyawan yang tinggi. Analisis data secara statistik menunjukkan koefisien jalur sebesar 0,363 dengan nilai $t$ statistics sebesar 4,55. Insentif finansial berpengaruh positif dan signifikan terhadap kinerja karyawan yang artinya insentif finansial yang tinggi akan mengarah pada kinerja karyawan yang tinggi. Analisis data secara statistik koefisien jalur sebesar 0,359 dengan 
nilai $t$-statistics sebesar 4,75. Insentif non finansial berpengaruh positif dan signifikan terhadap kinerja karyawan yang artinya insentif non finansial yang tinggi akan mengarah pada kinerja karyawan yang tinggi. Analisis data secara statistik yakni koefisien jalur sebesar 0,298 dengan nilai $t$-statistics sebesar 5,287.

Insentif finansial yang tinggi berdampak pada kepuasan kerja karyawan dimana dalam penelitian ini sebagai variabel mediasi sehingga kinerja karyawan pun akan meningkat. Analisis data statistik dengan nilai t-statistics sebesar 4,285. Berdasarkan tinjauan literatur, tampaknya semua jenis insentif penting tetapi mereka memiliki arti yang berbeda untuk karyawan. Insentif non finansial menunjukkan bahwa nilai t-statistics sebesar 2,559 sehingga pengaruh positif yang signifikan dengan kinerja kerja melalui kepuasan kerja sebagai variabel pemediasi. Insentif non finansial yang tinggi berdampak pada kepuasan kerja karyawan sehingga kinerja karyawan pun akan meningkat.

Berdasarkan kesimpulan di atas, saran yang dapat diberikan untuk pihak manajemen dalam meningkatkan kinerja karyawan perlu menyadari pentingnya kepuasan karyawan terlebih dahulu. Kepuasan kerja dipengaruhi dari banyak variabel sehingga harus mencari tahu terlebih dahulu variabel mana yang sangat mempengaruhi. Meningkatkan insentif finansial dan insentif non finansial yang diberikan kepada karyawan serta adanya keterbukaan dengan karyawan terkait dengan pemberian service charge. Karyawan akan merasa insentif finansial yang mereka dapatkan sudah sesuai dengan pendapatan hotel senyatanya jika hal tersebut dilakukan. Selain itu, dapat memberikan promosi jabatan kepada setiap karyawan jika ada kekosongan dalam posisi jabatan tertentu. Hal tersebut akan meningkatkan kinerja karyawan karena merasa dihargai atas pengabdian dan keahlian yang dimiliki karyawan.

Pihak Manajemen dapat memperhatikan juga pemberian insentif non finansial kepada karyawan berupa outing/gathering yang akan sangat berguna dalam memberikan pembaharuan suasana kerja dan mempererat hubungan antara Pihak Manajemen dan karyawan sehingga memberikan stimulus yang baik untuk kinerja karyawan. Pemimpin perusahaan diharapkan mampu berperan aktif dalam memediasi komunikasi antara karyawan dan Pihak Manajemen serta meninjau kembali indikator-indikator yang membentuk variabel insentif finansial dan non finansial dalam penelitian ini sehingga dapat melihat secara nyata dan langsung indikator mana yang lebih dominan membentuk kepuasan kerja karyawan.

\section{DAFTAR PUSTAKA}

Adisaksana, H., Astuti, E. S., \& Musadieq, M. Al. (2015). Pengaruh Pelatihan Kerja dan Insentif Terhadap Kepuasan Kerja dan Dampaknya Terhadap Komitmen Organisasional. Wacana, Jurnal Sosial Dan Humaniora, 18(02), 136-145. https://doi.org/10.21776/ub.wacana.2015.018.02.7

Al-Nsour, M. (2011). Relationship between Incentives and Organizational Performance for Employees in the Jordanian Universities. International Journal of Business and Management, 7(1), 78-89. https://doi.org/10.5539/ijbm.v7n1p78

Arindiah, C. D. (2010). Pengaruh pemberian insentif terhadap kinerja melalui kepuasan kerja (studi pada karyawan Persada Swalayan Malang). ,Pengaruh Pemberian Insentif Terhadap Kinerja Melalui Kepuasan Kerja (Studi Pada Karyawan Persada Swalayan Malang), 2010(2010), 1-99. https://doi.org/2010

Bishop, J., Bishop, \& John. (1987). The Recognition and Reward of Employee Performance. Journal of Labor Economics, 5(4), S36-56. https://econpapers.repec.org/RePEc:ucp:jlabec:v:5:y:1987:i:4:p:s36-56

Huang, S.-M., \& Lai, W.-H. (2014). A Study of the effect of incentive system on job performance -Locus of control as a moderator. The Journal of International Management Studies, 9(1), 89-98. 
Pengaruh Insentif Finansial dan Non Finansial terhadap Kinerja Karyawan Hotel Timeshare dengan variable..

Ni Luh Dita Priliani, Ida Ayu Putri Widawati, Irene Hanna H. Sihombing

Indrasari, D. M. (2017). Kepuasan Kerja dan Kinerja Karyawan Tinjauan dari Dimensi Iklim Organisasi , Kreatifitas Individu, dan Karakteristik Pekerjaan. Indomedia Pustaka.

Jawabreh, O., \& Alsarayreh, M. (2017). Analysis of job satisfaction in the hotel industry: A study of hotels five- Stars in aqaba special economic zone authority (AZEZA). International Journal of Applied Business and Economic Research, 15, 389-407. https://www.researchgate.net/publication/323080434_Analysis_of_job_satisfaction _in_the_hotel_industry_A_study_of_hotels_five-

_Stars_in_aqaba_special_economic_zone_authority_AZEZA/link/5afa79e0a6fdccacab 16ac54/download

Jaworski, C., Ravichandran, S., Karpinski, A. C., \& Singh, S. (2018). International Journal of Hospitality Management The e ff ects of training satisfaction, employee benefits , and incentives on part-time employees ' commitment. International Journal of Hospitality Management, 74(October 2017), 1-12.

Kashyap, H., \& Goyal, A. (2006). New Dimensions in E-governance A study on Factors Influencing Employee Job Satisfaction in Hotel Industry: A study with Reference to Hotels in Jaipur. 161-168.

Khan, I., Shahid, M., Nawab, S., \& Wali, S. S. (2013). Academic Research International Influence Of Intrinsic And Extrinsic Rewards On Employee Performance: The Banking Sector Of Pakistan. Academic Research International, 4(1), 282-291. www.savap.org.pkwww.savap.org.pkwww.journals.savap.org.pk

Kuznetsova, A. (2015). The Impact of a ' Financial Incentive Program ' on Employee Performance: The HRC case. The Impact of a "Financial Incentive Program" on the Employee Performance: The HRC Helsinki Case, 15.12.2015, 49. https://www.theseus.fi/bitstream/handle/10024/103692/The+Impact+of+a+Fina ncial+Incentive+Program+on+Employee+Performance.pdf;jsessionid=23A0AAE114 742FCAE51AD0E0DF625207?sequence=1

Mayastinasari, V. (2013). the Effect of Reward and Job Satisfaction on the Police Personnel Performance in the Riau Police Headquarters. Journal of Economics, Business, and Accountancy / Ventura, 16(3), 409. https://doi.org/10.14414/jebav.v16i3.221

McQuillan, J. (1996). The effects of incentives on reading. Reading Research and Instruction, 36(2), 111-125. https://doi.org/10.1080/19388079709558232

Ndege, H. O. (2014). Effects of reward on employee perfromance in hotels in North Coast, Kenya. Thesis(Business Administration School of Business, University of Nairobi.). http://erepository.uonbi.ac.ke/bitstream/handle/11295/75415/Ndede_+Effects+of +reward+management+on+employee+performance+in+hotels+in+North+coast $\% 2 \mathrm{C}$ +Kenya.pdf?sequence=1http://erepository.uonbi.ac.ke/bitstream/handle/11295/7 5415/Ndede_+Effects+of+reward+ma

Ndichu, J. N. (2017). Effects Of Incentives And Rewards On Employee Productivity In Small Banks In Kenya: A Case Study Of First Community BANK. Journal of Chemical Information and Modeling, 21(2), 1689-1699.

https://www.oecd.org/dac/accountable-effective-institutions/Governance Notebook 2.6 Smoke.pdf

O’Reilly, C. A., III, \& Pfeffer, J. (2000). Hidden Value: How Great Companies Achieve Extraordinary Results with Ordinary People - HBS Working Knowledge - Harvard Business School. https://hbswk.hbs.edu/archive/hidden-value-how-greatcompanies-achieve-extraordinary-results-with-ordinary-people

Puspitawati, Ni Made Dwi, \& Riana, I. G. (2014). Pengaruh Kepuasan Kerja Terhadap Komitmen Organisasional Dan Kualitas Layanan. Jurnal Manajemen, Strategi Bisnis Dan Kewirausahaan, 8(1), 68-80. https://doi.org/10.24843/MATRIK:JMBK

Plessis, A. J., Douangphichit, N., \& Dodd, P. (2015). Hrm in Relation To Employee Motivation and Job Performance. Journal of Business Research, 1-24. 
https://unitec.researchbank.ac.nz/bitstream/handle/10652/3375/9 th IBC Dup Nalinh Pat sent29-6.pdf?sequence=1\&isAllowed=y

Sugiyono. (2007). Metode Penelitian Bisnis. Alfabeta.

Wardhani, W. K., Susilo, H., \& Iqbal, M. (2015). Pengaruh Motivasi Kerja Karyawan Terhadap Komitmen Organisasional Dengan Kepuasan Kerja Sebagai Variabel Intervening. Jurnal Administrasi Bisnis (JAB), 2(1), 10-17. administrasibisnis.studentjournal.ub.ac.id

Whetten, D. A. \& C. K. S. (2007). Developing Management Skills / Pearson. https://www.pearson.com/us/higher-education/product/Whetten-DevelopingManagement-Skills-7th-Edition/9780131747425.html

Yang, H. (2008). Efficiency Wages And Subjective Performance Pay. Economic Inquiry, 46(2), 179-196. https://doi.org/10.1111/J.1465-7295.2007.00069.X

Vaishali, S., \& Ms.Jyotsna, S. (2015). Job Satisfaction and Job Performance: Linkages in Real World. Journal of Management Engineering and Information Technology, 2(2), 37-44. www.jmeit.com

Zaputri, A. R., Rahardjo, K., \& Utami, H. N. (2013). Pengaruh Insentif Material Dan Non Material Terhadap Kepuasan Kerja dan Kinerja Karyawan. Jurnal Administrasi Bisnis, $1-8$.

http://administrasibisnis.studentjournal.ub.ac.id/index.php/jab/article/view/110/ 178 